\title{
Geospatial assessment of land use and land cover dynamics in the mid-zone of Ghana
}

\author{
Addo Koranteng ${ }^{1} \bowtie$, Isaac Adu-Poku ${ }^{2}$, Emmanuel Donkor ${ }^{3}$, Tomasz Zawiła-Niedźwiecki ${ }^{4}$ \\ ${ }^{1}$ Kumasi Technical University, Institute of Research, Innovation and Development, Kumasi, Ghana, \\ e-mail:dr.adokay@gmail.com \\ ${ }^{2}$ Kwame Nkrumah University of Science and Technology, Geomatic Engineering Department, Kumasi, Ghana \\ ${ }^{3}$ Resource Management Support Centre of Forestry Commission, Kumasi,Ghana \\ ${ }^{4}$ Coordination Centre for Environmental Projects, Bitwy Warszawskiej 1920 r. 3, 02-362 Warszawa, Poland
}

\begin{abstract}
Land use and land cover (LULC) terrain in Ghana has undergone profound changes over the past years emanating mainly from anthropogenic activities, which have impacted countrywide and sub-regional environment. This study is a comprehensive analysis via integrated approach of geospatial procedures such as Remote Sensing (RS) and Geographic Information System (GIS) of past, present and future LULC from satellite imagery covering Ghana's Ashanti regional capital (Kumasi) and surrounding districts. Multi-temporal satellite imagery data sets of four different years, 1990 (Landsat TM), 2000 (Landsat ETM+), 2010 (Alos and Disaster Monitoring Constellation-DMC) and 2020 (SENTINEL), spanning over a 30-year period were mapped. Five major LULC categories - Closed Forest, Open Forest, Agriculture, Built-up and Water - were delineated premised on the prevailing geographical settings, field study and remote sensing data. Markov Cellular Automata modelling was applied to predict the probable LULC change consequence for the next 20 years (2040). The study revealed that both Open Forest and Agriculture class categories decreased 51.98 to 38.82 and 27.48 to 20.11, respectively. Meanwhile, Built-up class increased from 4.8\% to $24.8 \%$ (over $500 \%$ increment from 1990 to 2020). Rapid urbanization caused the depletion of forest cover and conversion of farmlands into human settlements. The 2040 forecast map showed an upward increment in the Builtup area up to $35.2 \%$ at the expense of other LULC class categories. This trend from the past to the forecasted future would demand that judicious LULC resolutions have to be made to keep Ghana's forest cover, provide arable land for farming activities and alleviate the effects of climate change.
\end{abstract}

\section{KEY WORD}

LULC change, anthropogenic pressures, Cellular-Automata-Markov, forest loss, urbanization 


\section{INTRODUCTION}

Land use and land cover (LULC) dynamics globally are vital landscape processes capable of modifying the fluxes of biotic and abiotic components and how they interact with each other (Ronchi 2018; Bekele et al. 2019). Anthropogenic modifications of the earth's surface are reckoned to have reached unparalleled magnitude, and the alterations in land use and land cover (LULC) are estimated as very significant globally (Melese 2016; Zhang et al. 2015).

LULC change studies are widely used to monitor human-induced changes in the environment. Many studies conducted all over the world acknowledge that land use and land cover change (LULCC) is the result of complex anthropogenic-environmental interactions (Goswami et al. 2019; Issa 2018; Qader et al. 2016). Kleemann et al. (2017) advance that high interdependencies in social-ecological systems make it difficult to identify the main drivers. They acknowledge that the key drivers of LULC changes, including indirect (underlying) drivers, which cannot be easily determined by spatial or economic analyses, are essential for land use planning especially in developing countries. Changes in land cover have a direct impact on forest ecosystem goods and services (Navarro-Cerrillo et al. 2019). For example, agricultural extensification due to increases in global food demand and production such as oil palm plantation expansion constitutes a major emerging challenge for forest conservation, particularly in the Amazonia and other tropical forest regions (Glinskis and Gutiérrez-Vélez 2019). Acheampong et al. (2018) add that the surging levels of urbanization in the world have added to the loss of forests and agricultural lands in many exurban zones, and in many cases, worsened poverty levels of smallholder farmers who depend on subsistence farming.

Remote Sensing (RS) and Geographic Information System (GIS) are essential tools in obtaining accurate and timely spatial data of LULC, as well as analysing the changes in a study area (Pervez et al. 2016; Srivastava et al. 2013). RS images efficiently record LULC conditions and offer a tremendous source of data, from which updated LULC information and changes can be extracted, analysed and simulated efficiently in the detection and monitoring of land uses at different scales (Rai et al., 2017; Singh et al., 2017). GIS on the other hand offers a flexible environment for collecting, storing, displaying and analysing digital data necessary for change detection (Panwar and Malik 2017). Although there are several methods for detecting and analysing LULC changes (Lu et al. 2004; Ayele et al. 2018), RS and GIS approaches make it possible to effectively monitor and forecast the trends in LULC changes via the study of historical remotely sensed imagery. This could offer a foundation for systematic and effective land use planning, management and ecological restoration for socioeconomic development (Liping et al. 2018).

Several methods for forecasting LULC changes are widely available in literature. These methods differ based on purposes, methodologies, geographic areas of the analysis, assumptions and both the source and type of data employed (Michetti and Zampieri 2014). The analytical equation-based models (Shamsi 2010) are often employed for estimating LULC changes. There are also the statistical models (Aitkenhead and Aalders 2009; Hyandye 2015), Markov models (Guan et al. 2019), multi-agent models (Ralha et al. 2013), expert system models (Stefanov et al. 2001), cellular models (Singh et al. 2015) and hybrid models (Subedi et al. 2013). Currently, the most extensively used models in LULC change monitoring and prediction are the cellular and agent-based models or the mixed model based on these two types of models (Sohl and Claggett 2013; Zhao and Peng 2012; Stevens and Dragićević 2007). The Markov chain and Cellular Automata (CA-Markov) model, one of the mixed models, is the hybrid of the Cellular Automata and Markov models. This model effectively combines the advantages of the long-term predictions of the Markov model and the capability of the Cellular Automata (CA) model to simulate the spatial variation in a complex system, and this mixed model can effectively simulate land cover changes ( $\mathrm{He}$ et al. 2018). The use of the CA-Markov model in LULC change studies has advantages such as its dynamic simulation capability; high efficiency with data, scarcity and simple calibration; and ability to simulate multiple land cover types and complex patterns (Hyandye and Martz 2017; Memarian et al. 2012). Many researchers have applied the CA-Markov model to monitor land use and landscape changes and predictions (Etemadi et al. 2018; Rimal et al. 2017; Mansour et al. 2020; Mosammam et al. 2017).

This study appraises LULC from 1990-2020 and projects into the future (2040) through geospatial analy- 
sis in the mid zone of Ghana. This study offers vital information for comprehensive countrywide and local environment change and sustainable development, and useful for planning and management for decision-makers.

\section{Study AREA AND DATA}

The study area is in the Ashanti Region, located centrally in the middle belt of Ghana and it lies within longitude $1^{\circ} 58^{\prime} \mathrm{W}$ and $1^{\circ} 11^{\prime} \mathrm{W}$ and latitude $6^{\circ} 22^{\prime} \mathrm{N}$ and $7^{\circ} 11^{\prime} \mathrm{N}$. This study focuses on the capital Kumasi and its adjoining districts, as seen in Figure 1. The adjoining districts include the following: Ejisu Juaben, Afigya Kwabre, Atwima Kwanwoma, Kwabre, Sekyere East, Atwima Nwabiagya and Bosomtwe. Ashanti Region has been the most populous region in Ghana in all the census years from 1960 to 2010 (GSS, 2013). The population of the region is projected at 5,792,200 in 2019 and falls within a semi-deciduous forest zone undergoing degradation consequently on anthropogenic actions. The cli- mate conditions in the study area features both wet and dry conditions with constant temperature throughout the course of the year, an average of $1400 \mathrm{~mm}$ of rain per year. The wet climate starts from March to November and the dry continues till February. The topography of the study area is undulating with a number of rivers running through the study area, and has an average elevation of $250 \mathrm{~m}$ above Mean Sea Level (MSL). The main source of potable water for Kumasi populace is from the Owabi and Barekese head works.

This study is based on the data sources listed in Table 1. It has been categorized into two: EO (earth observation) data and reference data, and has employed multitemporal satellite images of Landsat, TM (thematic mapper) and $\mathrm{ETM}+($ enhanced thematic mapper plus) images of scene 194/55 and 194/56 acquired in the years 1990 and 2000, 2010 ALOS of three scenes (Scene 38, 39 and 50 ) and one scene of 2010 DMC images and one scene of 2020 Sentinel image. The Landsat and Sentinel data were downloaded from the USGS (U.S. Geological Survey) database using its Glovis facility where the ALOS and

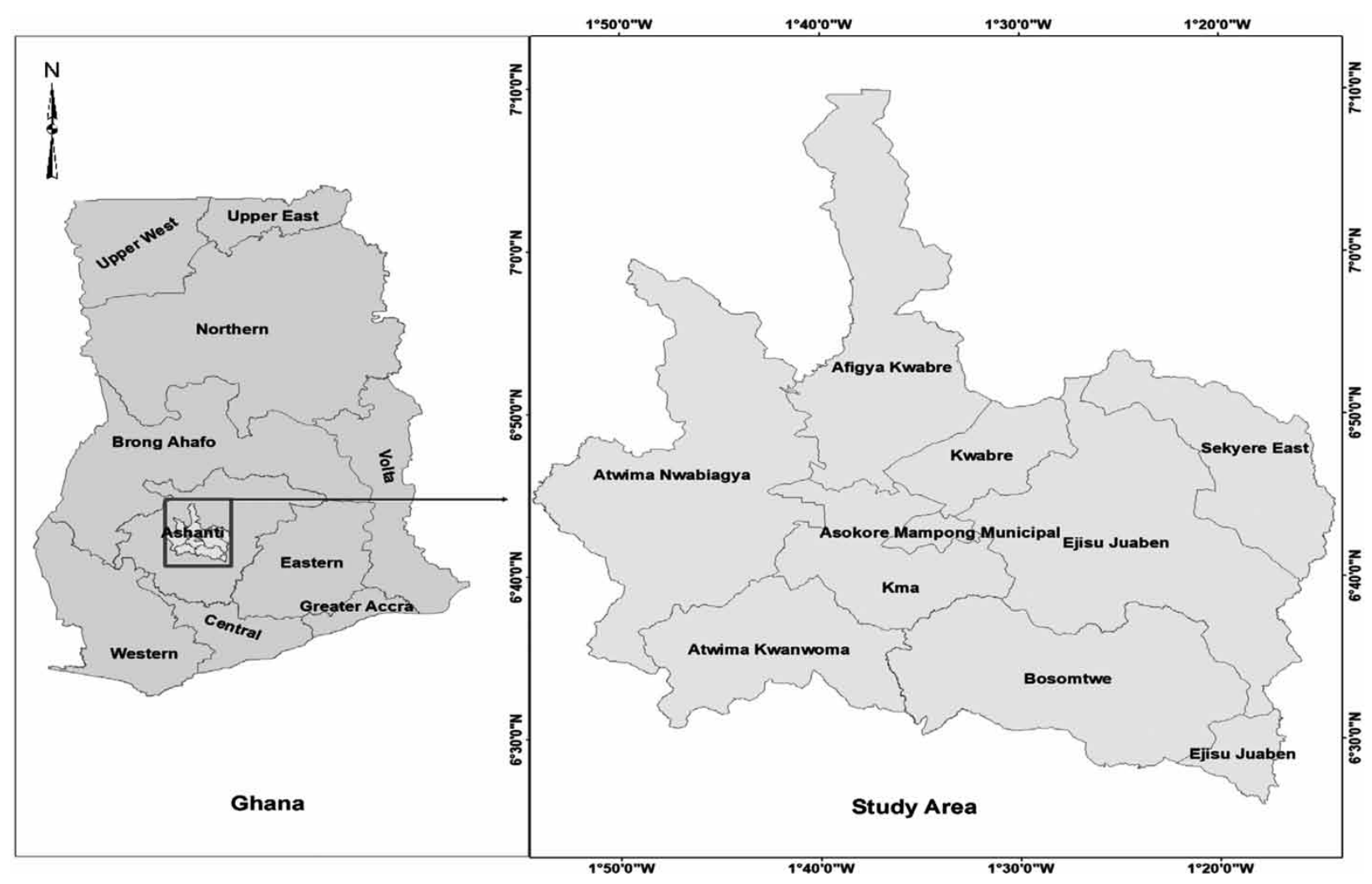

Figure 1: Map of Ghana showing the study area (Ashanti region, Ghana) 
DMC were obtained from the Forestry Commission of Ghana. These images were selected on the basis of availability, season and cloud coverage. The reference data include 1990 and 2000 Land Cover maps, topographical maps and aerial photographs of the study area.

Table 1. Data Acquisition and Source

\begin{tabular}{|l|l|l|l|}
\hline \multicolumn{1}{|c|}{ EO Data } & $\begin{array}{l}\text { Acquisi- } \\
\text { tion date }\end{array}$ & $\begin{array}{c}\text { Resolu- } \\
\text { tion }\end{array}$ & \multicolumn{1}{|c|}{ Source } \\
\hline LandSat TM & $\begin{array}{l}\text { December, } \\
1990\end{array}$ & $30 \mathrm{~m}$ & $\begin{array}{l}\text { USGS EROS } \\
\text { Centre }\end{array}$ \\
\hline LandSat ETM+ & $\begin{array}{l}\text { March, } \\
2000\end{array}$ & $30 \mathrm{~m}$ & $\begin{array}{l}\text { USGS EROS } \\
\text { Centre }\end{array}$ \\
\hline $\begin{array}{l}\text { DMC (Disaster } \\
\text { Management } \\
\text { Constellation) }\end{array}$ & $\begin{array}{l}\text { January, } \\
2010\end{array}$ & $22 \mathrm{~m}$ & $\begin{array}{l}\text { Forestry Commis- } \\
\text { sion, Ghana }\end{array}$ \\
\hline ALOS Image & $\begin{array}{l}\text { January, } \\
2010\end{array}$ & $10 \mathrm{~m}$ & $\begin{array}{l}\text { Forestry Commis- } \\
\text { sion, Ghana }\end{array}$ \\
\hline Sentinel Image & $\begin{array}{l}\text { January, } \\
2020\end{array}$ & $10 \mathrm{~m}$ & $\begin{array}{l}\text { USGS EROS } \\
\text { Centre }\end{array}$ \\
\hline \multicolumn{3}{|c|}{ Reference Data } \\
\hline $\begin{array}{l}\text { Topographical } \\
\text { Map }\end{array}$ & 2012 & $1: 50,000$ & $\begin{array}{l}\text { Survey \& Mapping } \\
\text { Division, Ghana }\end{array}$ \\
\hline $\begin{array}{l}\text { Aerial } \\
\text { Photographs }\end{array}$ & 2010 & $1: 10,000$ & $\begin{array}{l}\text { Survey \& Mapping } \\
\text { Division, Ghana }\end{array}$ \\
\hline $\begin{array}{l}\text { Land Cover } \\
\text { Map }\end{array}$ & $\begin{array}{l}1990 \& \\
2000\end{array}$ & $1: 10,000$ & $\begin{array}{l}\text { CERGIS, Univer- } \\
\text { sity of Ghana }\end{array}$ \\
\hline
\end{tabular}

were merged into three different composite images. The 2010 DMC, the individual scenes of Landsat images were subsequently resampled to $10 \mathrm{~m}$ resolution for better change detection analysis. The images were subsequently enhanced using Histogram Equalization. The 1990 and 2000 Landsat images were found to be hazy and were corrected.

\section{Image Classification and Accuracy Assessment}

To ensure quality results from change detection, a total of 160 ground truth data were taken at random evenly distributed on site. Using a total of 60 training points coupled with the local knowledge and Google Earth images, the 2020 image were classified and the remaining 100 points were used to assess the accuracy of the image classification. A supervised classification based on maximum likelihood was employed to classify the study area into five (5) land use categories: (1) Close Forest; (2) Open Forest; (3) Agriculture Lands; (4) Built-up; and (5) Water. The 2010 ALOS images were classified using the 2010 aerial photographs covering the study area, while the 2000 and 1990 Landsat images were conducted based on the land cover Map of Ghana obtained from CERGIS and prior "local knowledge" of the area. The various classified scenes of ALOS, DMC and Landsat images were then mosaicked into the individual classified maps (1990, 2000 and 2010 maps). All the various classified maps were later subset to our area of interest

\section{Methodology}

The steps undertaken in this study include image pre-processing, image classification, change detection and modelling, predicting change and validation. These steps are summarized in the flow chart display in Figure 2.

\section{Pre-processing}

Pre-processing is very important when it comes to analysing LULC change, as errors attributed to imaging sensors, atmospheric effects and curvature of the Earth, if not corrected, can lead to false results (Parsa et al. 2016). The individual bands of the downloaded satellite images (1990 and 2000 LandSat and 2020 Sentinel)

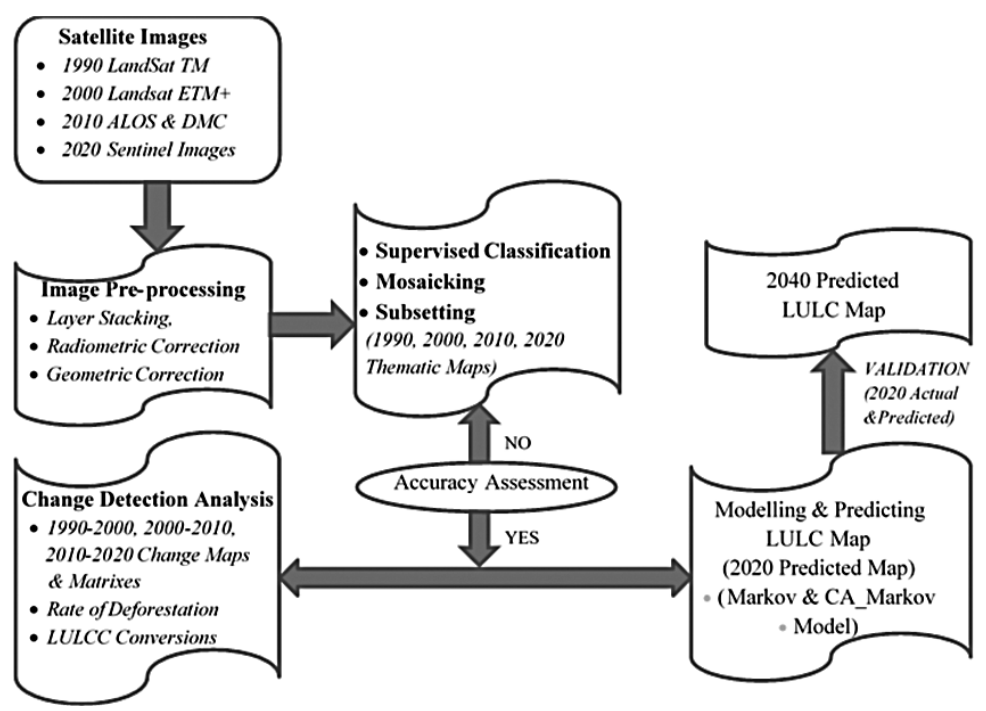

Figure 2: Flow chart depicting the steps undertaken in the geospatial analysis of land use/land 
Table 2. Land use classes

\begin{tabular}{|l|l|}
\hline \multicolumn{1}{|c|}{$\begin{array}{c}\text { Land use } \\
\text { Class }\end{array}$} & \multicolumn{1}{|c|}{ Feature } \\
\hline Close Forest & $\begin{array}{l}\text { All land with woody vegetation consistent with thresholds used to define Forest Land in the national greenhouse } \\
\text { gas inventory. It also includes systems with a vegetation structure that currently fall below, but in situ could } \\
\text { potentially reach the national threshold values used to define the Forest Land category in Ghana. }\end{array}$ \\
\hline Open Forest & $\begin{array}{l}\text { Cropped land, including rice fields, and plantation where the vegetation structure falls below the thresholds used } \\
\text { for the Forest Land category. Land where over 50 of any defined area is used for agriculture, this may be currently } \\
\text { cropped or in fallow and may include areas for grazing of livestock. }\end{array}$ \\
\hline Built Up & $\begin{array}{l}\text { All the developed land, including social utilities such as transportation infrastructure (roads and highways), built } \\
\text { up areas, bare grounds and human settlements of any size. }\end{array}$ \\
\hline Water & $\begin{array}{l}\text { These include lands that are covered or saturated by water for all or part of the year (for example, peatlands). It } \\
\text { also includes reservoirs and natural rivers and lakes. }\end{array}$ \\
\hline
\end{tabular}

Table 3A. Quantification of Land Cover Classes

\begin{tabular}{|l|r|r|r|r|r|r|r|r|}
\hline \multirow{2}{*}{ LULC CLASS } & \multicolumn{2}{|c|}{1990} & \multicolumn{2}{c|}{2000} & \multicolumn{2}{c|}{2010} & \multicolumn{2}{c|}{2020} \\
\cline { 2 - 9 } & area (ha) & area (\%) & area (ha) & area (\%) & area (ha) & area (\%) & area (ha) & area (\%) \\
\hline Close Forest & $39,748.81$ & 13.96 & $31,717.82$ & 11.14 & $41,137.82$ & 14.45 & $41,116.82$ & 14.44 \\
\hline Open Forest & $148,023.86$ & 51.98 & $132,088.89$ & 46.38 & $146,020.79$ & 51.27 & $110,549.87$ & 38.82 \\
\hline Agriculture & $78,262.61$ & 27.48 & $90,842.19$ & 31.90 & $52,497.69$ & 18.43 & $57,279.93$ & 20.11 \\
\hline Built Up & $13,596.11$ & 4.77 & $24,854.89$ & 8.73 & $39,620.82$ & 13.91 & $70,638.63$ & 24.80 \\
\hline Water & $5,148.85$ & 1.81 & $5,276.45$ & 1.85 & $5,503.12$ & 1.93 & $5,194.99$ & 1.82 \\
\hline Grand Total & $284,780.24$ & 100.00 & $284,780.24$ & 100.00 & $284,780.24$ & 100.00 & $284,780.24$ & 100.00 \\
\hline
\end{tabular}

Table 3B. Error Matrix of Image Classification

\begin{tabular}{|l|c|c|c|c|c|}
\hline \multicolumn{1}{|c|}{ Class } & $\begin{array}{c}\text { Refe- } \\
\text { rence }\end{array}$ & $\begin{array}{c}\text { Classi- } \\
\text { fied }\end{array}$ & $\begin{array}{c}\text { Num- } \\
\text { ber }\end{array}$ & $\begin{array}{c}\text { Produ- } \\
\text { cers }\end{array}$ & Users \\
\hline name & totals & totals & correct & accuracy & accuracy \\
\hline- & - & - & - & $(\%)$ & $(\%)$ \\
\hline Close Forest & 17 & 20 & 15 & 88.24 & 75.00 \\
\hline Open Forest & 33 & 30 & 25 & 75.76 & 83.33 \\
\hline Agriculture & 20 & 20 & 14 & 70.00 & 70.00 \\
\hline Built Up & 25 & 25 & 21 & 84.00 & 84.00 \\
\hline Water & 5 & 5 & 5 & 100.00 & 100.00 \\
\hline & Totals & 100 & 100 & 80 & \\
\hline & \multicolumn{7}{|c|}{ Overall Classification Accuracy } \\
$=80.00 \%$ & \\
\hline
\end{tabular}

(study area). Confusion matrix and kappa statistics were used to assess the accuracy of the 2020 classified image.
Table 3C. Kappa Statistics

\begin{tabular}{|c|c|}
\hline \multicolumn{2}{|c|}{ KAPPA $\left(\mathrm{K}^{\wedge}\right)$ STATISTICS } \\
\hline \multicolumn{2}{|c|}{ Overall Kappa Statistics $=0.7375$} \\
\hline Conditional Kappa for each Category \\
\hline Close Forest & 0.6988 \\
\hline Open Forest & 0.7512 \\
\hline Agriculture & 0.6250 \\
\hline Built Up & 0.7867 \\
\hline Water & 1.0000 \\
\hline
\end{tabular}

There were no available ground truth data to access the accuracy of the 1990, 2000 and 2010 classified images, however, the classification was based on the available land cover maps, aerial photos and local knowledge of the study area. 


\section{Change Detection Analysis}

The study employed a Post-Classification Change Detection in assessing the LULCC that have taken place over the thirty year period (1990-2020). Using LCM module of Idrisi Selva, a cross-tabulation of the two thematic maps of the same dimensions at a time can be analysed. With the 1990, 2000, 2010 and 2020 thematic maps as input to LCM, the following results were generated for the three time epochs (1990-2000, 2000-2010, 2010-2020): 1) net gains or losses in hectares (ha) and percentages (\%) for each land-cover category; (2) contributors to the net change by each land-cover type; (3) change maps; (4) change matrices; and (5) matrices of transition probabilities to provide information on the probability associated with a land-cover class either remaining unchanged or changing to one of the other classes. To calculate the annual rate of LULC change, the following equation according to Menon and Bawa (1997) was adopted:

$$
r=100 \times \frac{A 2-A 1}{A 1} \times \frac{1}{t 2-t 1}
$$

where:

$r \quad$ - the rate of LULC change,

$A 1, A 2$ - the area of the first epoch and second epoch, respectively,

$t 1, t 2$ - the year of the first epoch and second epoch, respectively.

Moreover, the extent of area that remained unchanged can be calculated as the summation of the area in the diagonal of the LULC Change matrix (Tab. 4A, $4 \mathrm{~B}$ and $4 \mathrm{C}$ ) and can be given in the formula $\mathrm{A}$ and the area coverage in percent can also be given in formula $\mathrm{B}$ :

$$
\begin{gathered}
A U=\sum\left(A_{11}+A_{22}+A_{33}+A_{44}+\cdots\right) \\
P \%=\frac{A U}{A_{T}}
\end{gathered}
$$

where:

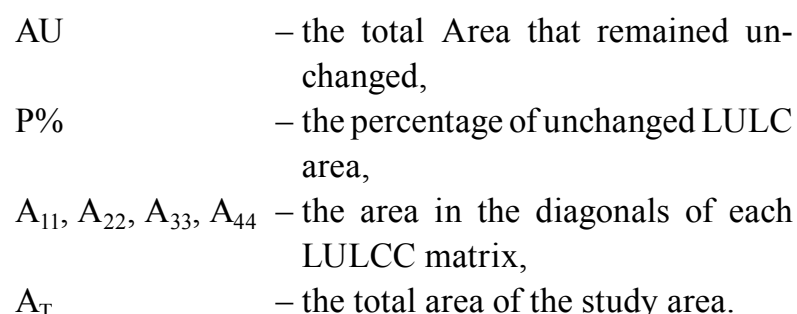

Modelling and Predicting LULC Change

In modelling and predicting LULC change, the study adopted the use of Markov Chain (MC) analysis and Cellular Automata (CA-Markov) to predict the landcover change. Markov Chain analysis determines the probability of land-cover changing from one period to another by developing a transition matrix between time t1 and time t2. Cellular Automata (CA) is integrated with Markov Chain analysis to deal with the spatial distribution issues Markov Chain Model faces. The CA component of the CA-Markov model allows the transition probabilities of one pixel to be a function of its neighbouring pixels. CA-Markov models and predicts the changes of several classes of cells by using the following generated outputs: a Markov transition matrix, a 'suitability' map, and a neighbourhood filter (Eastman 2009).

Sang et al. (2011), adds that the Markov model application in forecasting LULCC emanates from its ability to compute different and transition states among different land uses. Subedi et al. (2013) gives the homogeneous Markov model for forecasting LULCC mathematically as Eq. 1:

$$
\begin{gathered}
L_{(t+1)}=P_{i j} X L_{t} \\
\text { and } \\
P_{i}=\left[\begin{array}{cccc}
P_{11} & P_{12} & \ldots & P_{1 m} \\
P_{21} & P_{22} & \ldots & P_{2 m} \\
\vdots & \vdots & \ddots & \vdots \\
P_{m 1} & P_{m 2} & \ldots & P_{m}
\end{array}\right] \\
\left(\begin{array}{c}
0 \leq P_{I J}<1 \\
\text { and } \\
\sum_{j=1}^{m} P_{i j}=1, \quad i, j=1,2, \ldots, m
\end{array}\right)
\end{gathered}
$$

were:

$L_{(t+1)}, L_{(t)} \quad$ - the conditions of $\mathrm{LU}$ in $\mathrm{t}$ and $\mathrm{t}+1$ periods, respectively,

$P_{i j} \quad-$ a matrix of transition probability in one condition.

Muller and Middleton (1994) puts the Markov chain (Eq. 2) from the distribution of LU in the commencement (Mt) and the completion of a discrete time period $(\mathrm{Mt}+1)$ in addition to transition matrix $(\mathrm{MLc})$, which indicates the variations that have happened in the envisioned time period. Using this assumption, LU change 
Table 4A. 1990-2000 Change Matrix

\begin{tabular}{|c|c|c|c|c|c|c|c|}
\hline \multirow{2}{*}{\multicolumn{2}{|c|}{ LULC Class }} & \multicolumn{5}{|c|}{1990} & \multirow[b]{2}{*}{2000 Total } \\
\hline & & Close Forest & Open Forest & Agriculture & Built Up & Water & \\
\hline & & - & - & - & - & - & - \\
\hline \multirow{7}{*}{2000} & Close Forest & $14,447.53$ & $12,330.37$ & $4,819.09$ & 15.25 & 105.58 & $31,717.82$ \\
\hline & Open Forest & $20,565.11$ & $81,175.17$ & $29,881.12$ & 425.91 & 41.58 & $132,088.89$ \\
\hline & Agriculture & $4,562.07$ & $47,573.25$ & $34,104.43$ & $4,580.01$ & 22.43 & $90,842.19$ \\
\hline & Built Up & 113.95 & $6,719.35$ & $9,445.44$ & $8,572.64$ & 3.51 & $24,854.89$ \\
\hline & Water & 60.15 & 225.72 & 12.53 & 2.3 & $4,975.75$ & $5,276.45$ \\
\hline & & - & - & - & - & - & - \\
\hline & 1990 Total & $39,748.81$ & $148,023.86$ & $78,262.61$ & $13,596.11$ & $5,148.85$ & $284,780.24$ \\
\hline
\end{tabular}

Table 4B. 2000-2010 Change Matrix

\begin{tabular}{|c|c|c|c|c|c|c|c|}
\hline \multirow{2}{*}{\multicolumn{2}{|c|}{ LULC Class }} & \multicolumn{5}{|c|}{2000} & \multirow[b]{2}{*}{2010 Total } \\
\hline & & Close Forest & Open Forest & Agriculture & Built Up & Water & \\
\hline & & - & - & - & - & - & - \\
\hline \multirow{7}{*}{2010} & Close Forest & 12492.73 & 18097.74 & 10425.21 & 90.99 & 31.15 & 41137.82 \\
\hline & Open Forest & 17356.08 & 87745.69 & 40505.66 & 374.88 & 38.48 & 146020.79 \\
\hline & Agriculture & 1706.28 & 23004.45 & 26193.81 & 1580.99 & 12.16 & 52497.69 \\
\hline & Built Up & 66 & 3162.37 & 13588.85 & 22801.35 & 2.25 & 39620.82 \\
\hline & Water & 96.73 & 78.64 & 128.66 & 6.67 & 5192.41 & 5503.11 \\
\hline & & - & - & - & - & - & - \\
\hline & 2000 Total & 31717.82 & 132088.89 & 90842.19 & 24854.88 & 5276.45 & 284780.23 \\
\hline
\end{tabular}

Table 4C. 2010-2020 Change Matrix

\begin{tabular}{|c|c|c|c|c|c|c|c|}
\hline \multirow{2}{*}{\multicolumn{2}{|c|}{ LULC Class }} & \multicolumn{5}{|c|}{2010} & \multirow[b]{2}{*}{2020 Total } \\
\hline & & Close Forest & Open Forest & Agriculture & Built Up & Water & \\
\hline & & - & - & - & - & - & - \\
\hline \multirow{7}{*}{2020} & Close Forest & $13,204.16$ & $23,611.25$ & $4,136.11$ & 124.84 & 40.46 & $41,116.82$ \\
\hline & Open Forest & $15,664.31$ & $75,354.57$ & $18,980.52$ & 442.09 & 108.38 & $110,549.87$ \\
\hline & Agriculture & $8,049.39$ & $32,011.16$ & $15,242.33$ & $1,867.73$ & 109.32 & $57,279.93$ \\
\hline & Built Up & $4,219.96$ & $15,043.81$ & $14,138.73$ & $37,186.16$ & 49.97 & $70,638.63$ \\
\hline & Water & 0 & 0 & 0 & 0 & $5,194.98$ & $5,194.98$ \\
\hline & & - & - & - & - & - & - \\
\hline & 2010 Total & $41,137.82$ & $146,020.79$ & $52,497.69$ & $39,620.82$ & $5,503.11$ & $284,780.23$ \\
\hline
\end{tabular}


Table 4D. Extent of Unchanged/Change LULC Area for the three epochs

\begin{tabular}{|c|c|c|c|c|}
\hline \multirow{2}{*}{ Epoch } & \multicolumn{2}{|c|}{ Changed } & \multicolumn{2}{c|}{ Unchanged } \\
\cline { 2 - 5 } & area (ha) & area (\%) & area (ha) & area (\%) \\
\hline $1990-2000$ & $141,504.72$ & 49.69 & $143,275.52$ & 50.31 \\
\hline $2000-2010$ & $130,354.25$ & 45.77 & $154,425.99$ & 54.23 \\
\hline $2010-2020$ & $138,598.03$ & 48.67 & $146,182.2$ & 51.33 \\
\hline
\end{tabular}

Table 4E. Annual Rate of LULC Change

\begin{tabular}{|l|c|c|c|}
\hline LULC Class & $\begin{array}{c}1990-2000 \\
(\%)\end{array}$ & $\begin{array}{c}2000-2010 \\
\mathbf{( \% )}\end{array}$ & $\begin{array}{c}\text { 2010-2020 } \\
\mathbf{( \% )}\end{array}$ \\
\hline Close Forest & -2.0 & 3.0 & 0.0 \\
\hline Open Forest & -1.1 & 1.1 & -2.4 \\
\hline Agriculture & 1.6 & -4.2 & 0.9 \\
\hline Built Up & 8.3 & 5.9 & 7.8 \\
\hline Water & 0.2 & 0.4 & -0.6 \\
\hline
\end{tabular}

is projected based on the projected likelihoods and in the transition matrix:

$$
\begin{gathered}
{\left[\begin{array}{cccc}
L C_{u u} & L C_{u a} & L C_{u w} & \ldots \\
L C_{a u} & L C_{a a} & L C_{a w} & \ldots \\
L C_{w u} & L C_{w a} & L C_{w w} & \ldots \\
\ldots & \ldots & \ldots & \ldots
\end{array}\right]\left[\begin{array}{c}
U_{t} \\
A_{t} \\
W_{t} \\
\ldots
\end{array}\right]=\left[\begin{array}{c}
U_{t} \\
A_{t} \\
W_{t} \\
\ldots
\end{array}\right]} \\
M_{L C} X M_{t}=M_{t+1}
\end{gathered}
$$

Validation is important in modelling and predicting LULC maps. In order to validate the LULC prediction given by the CA-Markov model, a comparison is done between the actual LULC map and the predicted LULC map of the same year. Kappa statistics values are used to assess the agreements between the forecasted LULC map and the actual LULC map based on Kno (Kappa for no ability), Klocation (Kappa for location) and Kstandard (Kappa index). Kno indicates the proportion classified correctly relating to the expected proportion classified correctly by a simulation with no ability to specify accurately quantity or location. Klocation indicates how well the grid cells are located on the landscape. Kstandard (Kappa index) compares the observed proportion correct to the expected proportion, corrected due to chance (Pontius 2000).

The 2010-2020 land-cover maps were first used as inputs in Markov module to generate a transition matrix and a set of conditional probability images between the two dates of the thematic maps. These resulting outputs were later loaded in the CA-Markov module to generate the 2020 predicted map. Afterwards, the predicted 2020 land-cover map was compared with the actual land-cover map of 2020 for validation. Following the validation, the 1990-2020 land-cover maps were used to predict the 2040 land-cover map.

\section{Results}

\section{Image Classification and Accuracy Assessment}

The study area was classified into five (5) LULC classes based on supervised classification: Closed Forest, Open Forest, Agriculture, Built-up and Water. Figure 3 shows the four thematic maps generated for this study: 1990, 2000, 2010 and 2020 LULC Maps. Accuracy assessment is essential, and particularly so, when using postclassification change detection methods (Foody 2002; Behera et al. 2012). Accuracy assessment of the LULC Maps produced from the 1990, 2000, 2010 and 2020 were performed and assessment report was generated (Tab. 3B and 3C). Total classification accuracy of $80 \%$ was attained. Overall Kappa statistics of 0.7375 was realized for 2020 LULC. The Ghana Forest Preservation Program - report (FPP-Ghana, 2013) ground truthing and verification data was used for this activity. Accuracy assessments for 1990, 2000, 2010 images were undertaken through topographical map, aerial photograph, land cover map, digitized topographical data photographs, data and reference points from statutory bodies such as the Forestry Commission and Survey Department.

\section{LULC maps assessment}

Figure 3A, B, C and D indicate that the LULC maps for 1990, 2000, 2010 and 2020 show considerable change from one category (class) to another category. Table $3 \mathrm{~A}$ shows the extent of the area of individual LULC in hectares (ha) and expressed in percentages.

The land use/cover map for 1990 epoch (Fig. 3A) shows Close and Open forests constituting a little over $66 \%$ of the LULC; Agriculture is the next dominant LULC category; Built-up is shown as the second least category constituting less than $5 \%$ of the LULC and Water share of the LULC aggregating to $1.8 \%$ main- 

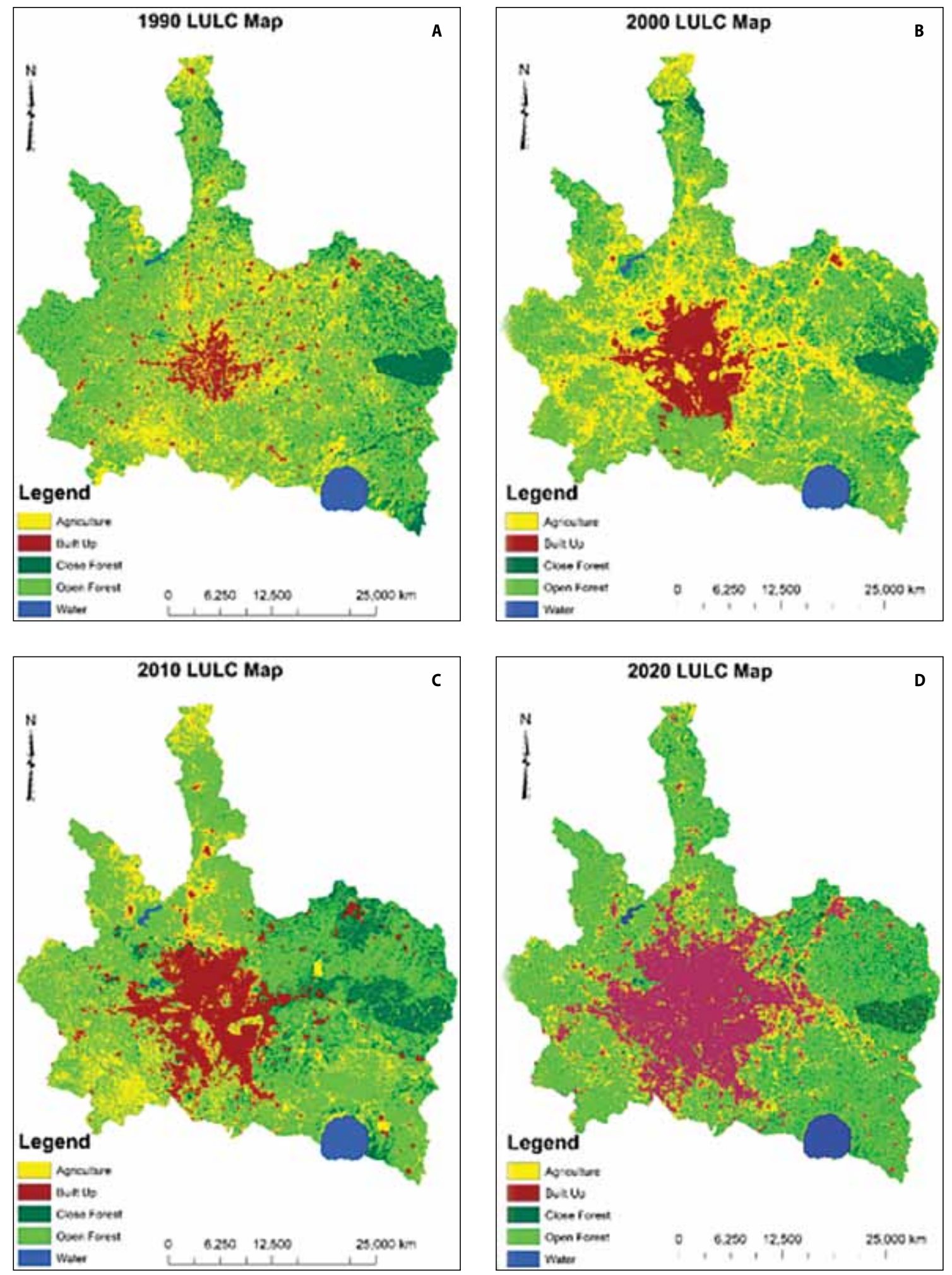

Figure 3. Image classification maps of the study area at different time 
ly from the lake Bosumtwi, the Barekese and Owabi Headworks and supplying rivers and streams.

Figure 3B shows the LULC map for 2000 with Close and Open forests reducing to $57 \%$, Agriculture gains marginally from $27.5 \%$ in 1990 to $32 \%$; Built-up almost doubles from $4.8 \%$ to $8.7 \%$ after the ten-year interval. Water part of the LULC remains constant.

The land use/cover map for 2010 (Fig. 3C) shows Close and Open forests rebound to the 1990 figures as a result of massive reforestation. Agriculture loses and drops to $14 \%$; Built-up continues to surge at the expense of Agriculture. Water share of the LULC remains constant.

Figure 3D shows the LULC map for 2020 in which Close and Open forests dipping to 53\%; Agriculture gains marginally from $18 \%$ to $20 \%$; Built-up surge continues from $14 \%$ to $25 \%$ after the ten-year interval. Water share of the LULC remains fairly constant.

\section{LULC Change Matrix}

The Table 4A, 4B and 4C show the extent of change in the area of the individual land cover categories in hectares (ha) and the percentage they occupied for 1990-2000, 2000-2010 and 2010-2020 respectively. Figure 4A, B and C, 5A, 5B and 5C provide illustra- tions of the changes that have transpired. Water share remained stable for all the stated periods.

A general observation depicts a drastic change from 1990 to 2000 (Fig. 4A and 5A) as Close and Open forests lost while Agriculture and Built-up area made gains. 49.69 of LULC changed, while 50.31 remained unchanged (Tab. 4D).

The LULC map continuously changed from 2000 to 2010 (Fig. 4B and 5B) as Close forest and Built-up gained, while Agriculture lost. This rapid development shows a positive impact towards urbanization and reforestation. 45.55 of LULC changed, while 54.23 remained unchanged (Tab. 4D).

Unceasingly, the LULC map changed from 2010 to 2020 (Figures 4C and 5C) as Open forest was cleared mostly for Built-up, while Agriculture stagnated. This rapid development showed positive impact towards urbanization as in the previous decade. 48.67 of LULC changed, while 51.33 remained unchanged (Tab. 4D).

\section{Annual Rate of LULC Change}

The annual Rate of LULC change for the 1990-2000, 2000-2010 and 2010-2020 showed varying rates of change (Tab. 4E). For Closed forest, there was a decrease in the yearly rate of $-2.0 \%$ for $1990-2000$, an
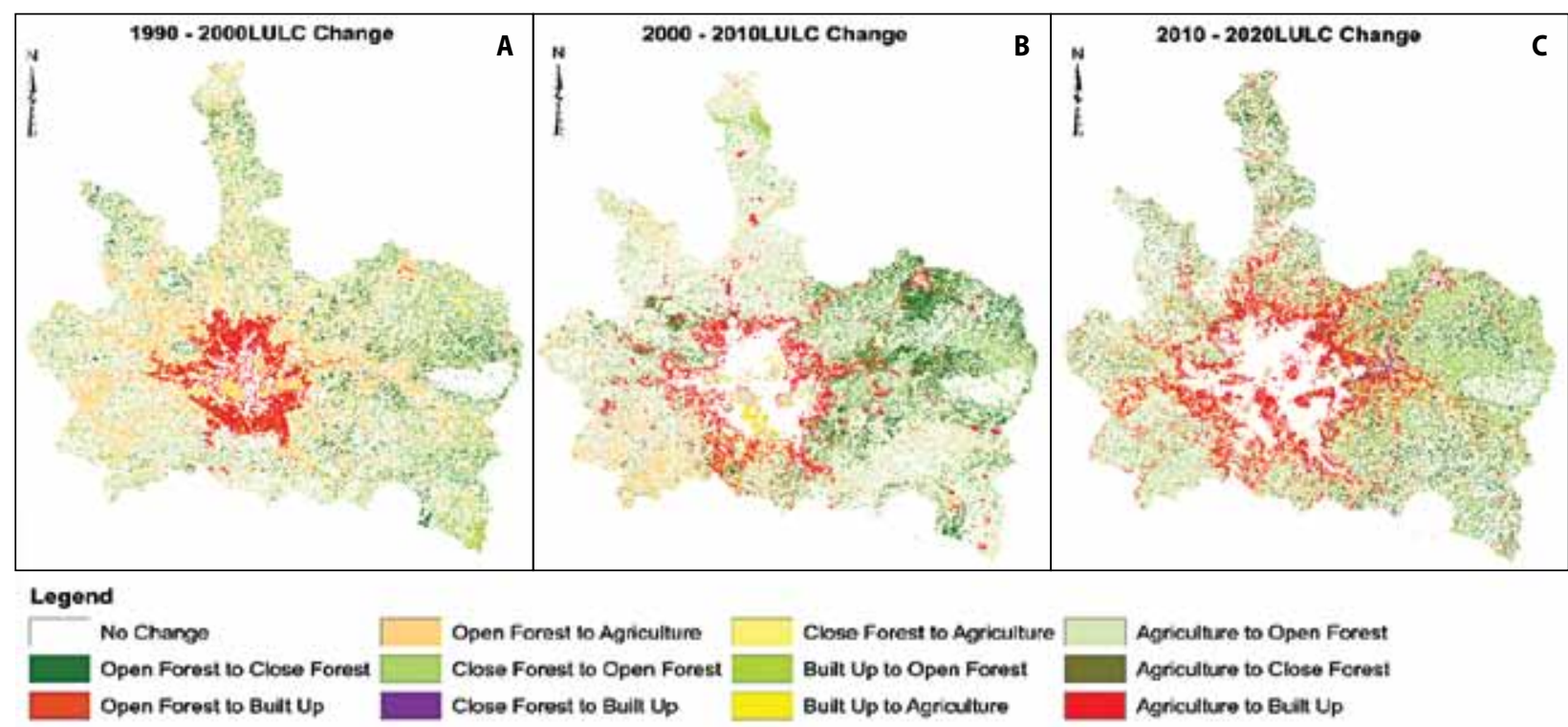

$\begin{array}{lll}0 & 6,250 & 12,500\end{array}$

$25.000 \mathrm{~km}$

Figure 4. Land use/land cover change maps of the study area 


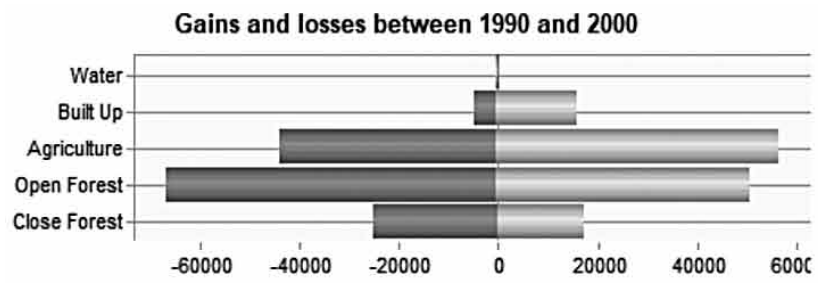

Contributions to Net Change in Close Forest

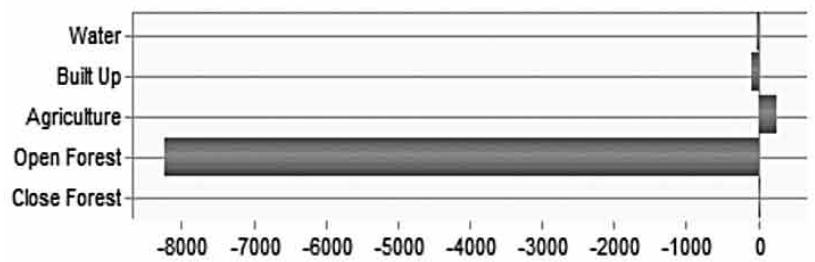

Contributions to Net Change in Agriculture

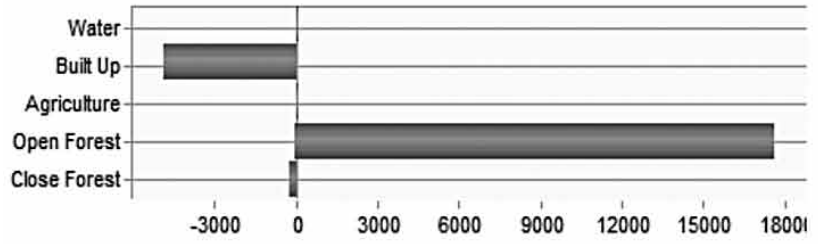

Figure 5A. Change analysis 1990-2000

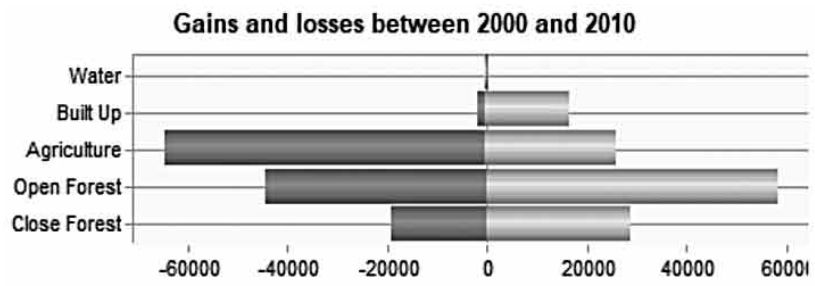

Contributions to Net Change in Close Forest

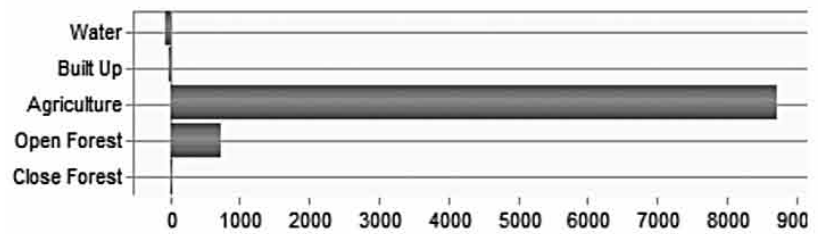

Contributions to Net Change in Built Up

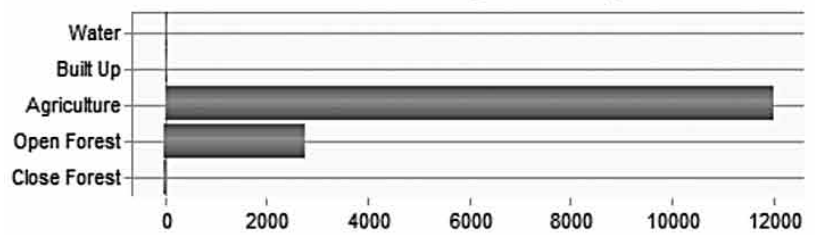

Figure 5B. Change analysis 2000-2010

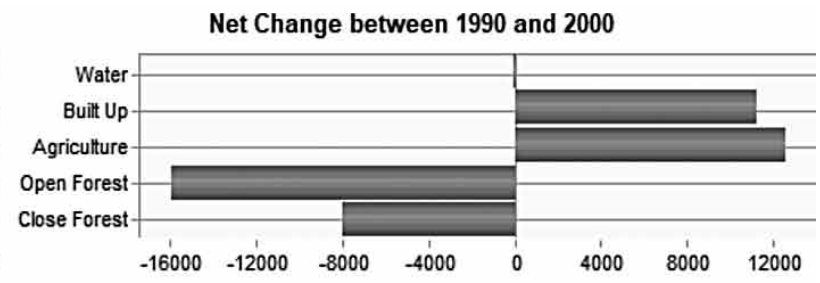

Contributions to Net Change in Open Forest

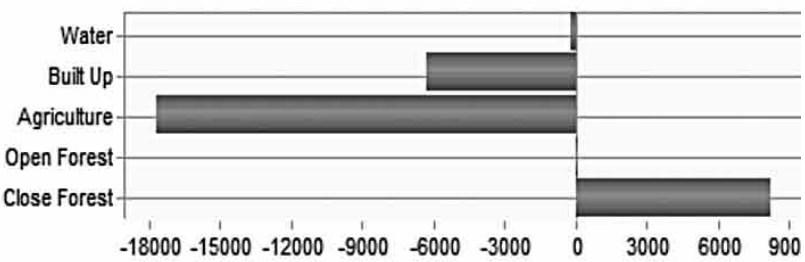

Contributions to Net Change in Built Up

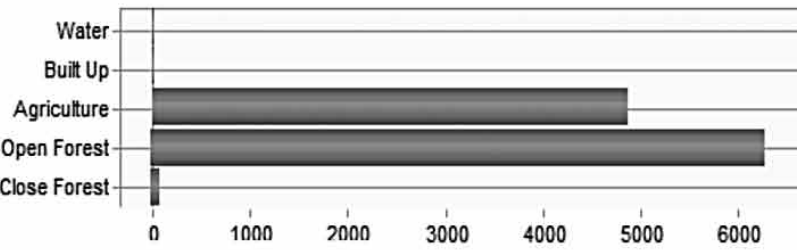

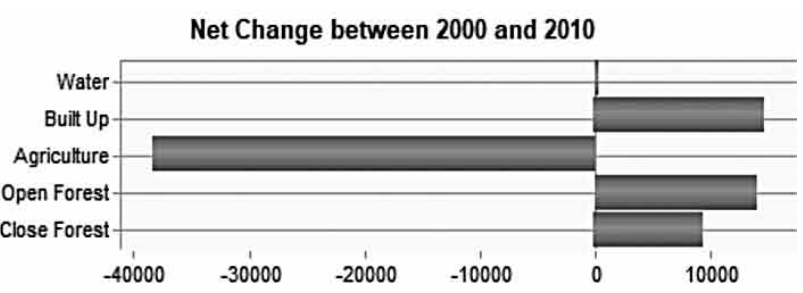

Contributions to Net Change in Open Forest

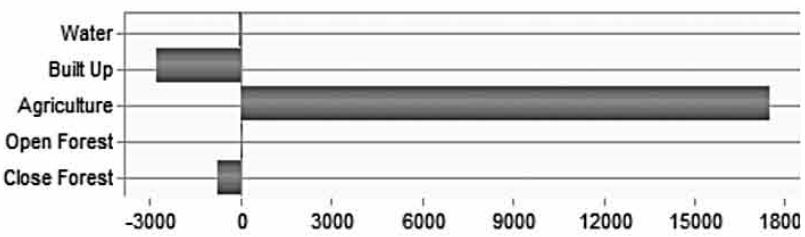

Contributions to Net Change in Agriculture

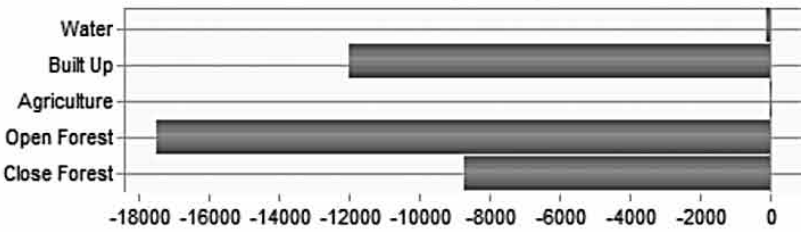



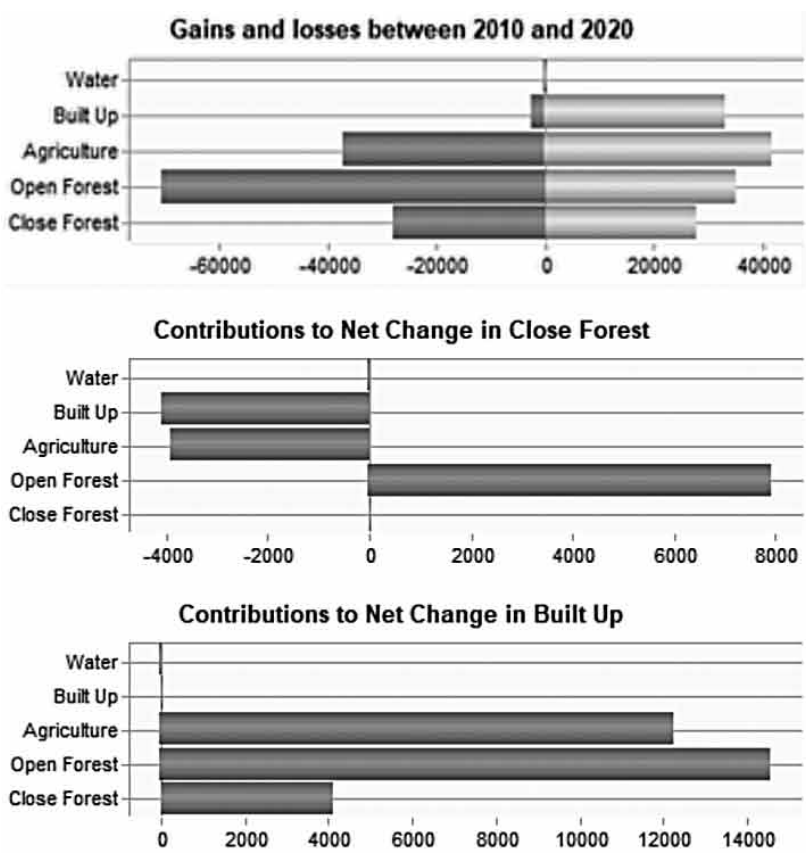

Figure 5C. Change analysis 2000-2020

increase of $3.0 \%$ for $2000-2010$ and no change for 2010-2020. In the case of Open forest, there was a decrease of $1.1 \%$ in $1990-2000$, an appreciation of $1.1 \%$ in 2000-2010 and a decrease of $2.4 \%$ for $2010-2020$. Agricultural LULC increased by $1.6 \%$ in $1990-2000$, decreased sharply by $4.2 \%$ in $2000-2010$ and gained marginally $0.9 \%$ in $2010-2020$. Built-up annual rate of change remained high throughout the stated periods. Water share remain fairly constant.

\section{Validating LULC prediction model and 2040 LULC simulated map}

To get satisfactory results and to authenticate the LULC estimates produced by the CA-Markov model, the computer-generated 2020 LULC extents were compared to the actual present 2020 land use areas. Assessment of simulated and classified map for the year 2020 is presented in Table 5A.

Table 5 specifies that Close forest area and water bodies had the best agreement. The computer-generated 2020 LULC areas expressed in percentages were $14.94 \%$ and $1.93 \%$ and the actuals were $14.44 \%$ and $1.82 \%$, respectively, for Close Forest and Water bodies. The simulated LULC map showed an overestimated share for Open forest at $50.56 \%$, while the Actual LULC map showed it to be $38.82 \%$. The simulated
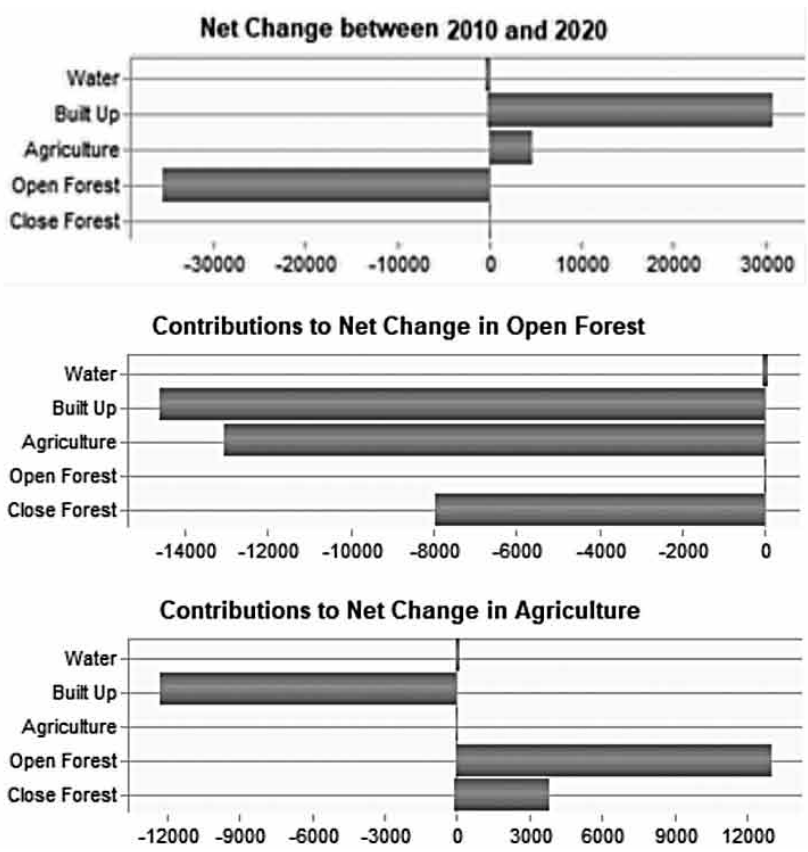

LULC map showed that Agriculture and Built-up areas were underestimated at $16.02 \%$ and $16.54 \%$, while the Actual LULC map put the figures at $20.11 \%$ and 24.80 .

Table 5. Comparison of 2020 Actual and Predicted LULC Maps

\begin{tabular}{|l|r|r|r|r|}
\hline \multirow{2}{*}{$\begin{array}{c}\text { LULC } \\
\text { Class }\end{array}$} & \multicolumn{2}{|c|}{$\begin{array}{r}\text { 2020 Actual } \\
\text { LULC Map }\end{array}$} & \multicolumn{2}{c|}{$\begin{array}{c}\text { 2020 Predicted } \\
\text { LULC Map }\end{array}$} \\
\cline { 2 - 5 } & area (ha) & area (\%) & (ha) & area (\%) \\
\hline $\begin{array}{l}\text { Close } \\
\text { forest }\end{array}$ & $41,116.82$ & 14.44 & $42,547.73$ & 14.94 \\
\hline Open forest & $110,549.87$ & 38.82 & $143,998.81$ & 50.56 \\
\hline Agriculture & $57,279.93$ & 20.11 & $45,620.54$ & 16.02 \\
\hline Built up & $70,638.63$ & 24.80 & $47,103.95$ & 16.54 \\
\hline Water & $5,194.99$ & 1.82 & $5,509.21$ & 1.93 \\
\hline Total & $284,780.24$ & 100.00 & $284,780.24$ & 100.00 \\
\hline
\end{tabular}

Statistical evaluation based on the Kappa coefficient was used to measure the overall agreement of matrix, the ratio diagonal values' summation versus the total number of pixel counts within the matrix and the non-diagonal elements would be the best approach to assess the model accuracy (Arsanjani et al. 2013). 
Arsanjani et al. (2013) posits that a kappa value of 0 illustrates the agreement between actual and reference map (equals chance agreement), the upper and lower limit of kappa is +1.00 (it occurs when there is total agreement) and -1.00 (it happens when there is less chance of agreement). The accuracy assessment process achieved by employing VALIDATE module in IDRISI Selva environment v. 17 produced K values $($ Kstandard $=0.6595 ;$ Kno $=0.7313 ;$ Klocation $=$ 0.7241 ; KlocationStrata $=0.7241$ ) above 0.8 , showing satisfactory level of accuracy. These values were

Table 6. Quantification of 2040 Predicted LULC

\begin{tabular}{|l|c|c|}
\hline LULC Class & Area (ha) & Area (\%) \\
\hline Close Forest & $36,588.07$ & 12.85 \\
\hline Open Forest & $93,682.74$ & 32.90 \\
\hline Agriculture & $49,077.53$ & 17.23 \\
\hline Built Up & $100,235.1$ & 35.20 \\
\hline Water & $5,196.8$ & 1.82 \\
\hline Total & $284,780.24$ & 100.00 \\
\hline
\end{tabular}

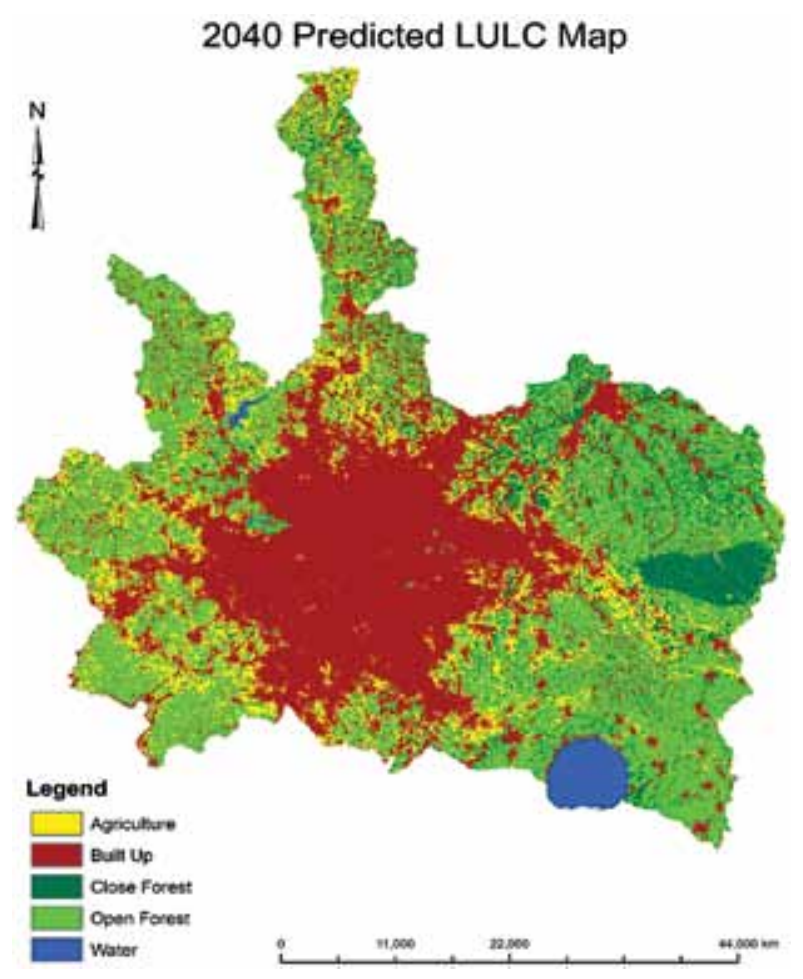

Figure 6. Predicted LULC Map for 20 years (2040) found to fall within the standard values suggested by Monserud \& Leamans (1992) that a value of kappa of $75 \%$ or greater showed a very good to excellent classifier performance, while a value less than $40 \%$ is poor.

Table 6 and Figure 6 show the simulated LULC map for 2040. The cumulative forest cover comprising both the Close and Open forests had reduced as the area are being converted for agricultural use and built-up purposes. Agriculture share declines as the area is converted into the construction of houses and social amenities. Built-up category is the highest gainer and this is mostly at the expense of Agriculture and now assumes the dominant LU class. Water level remains stable. This fast expansion shows the positive impact towards urbanization.

\section{LULC Trajectory for 1990-2040}

Figure 7 shows the trajectory of LULC from 1990-2040 covering 50 years. The diagram describes a worrying scenario for the forests. There is forest loss (deforestation and degradation) from as high as 66\% in 1990 to $44 \%$ by 2040 . Agricultural land will continue to decline paving way for more houses and social amenities to be provided. Built-ups' share would continue to be the fastest growing land use class from $4.8 \%$ in 1990 to $35.2 \%$ by 2040 . The water share will remain unchanged throughout the 50 years under consideration.

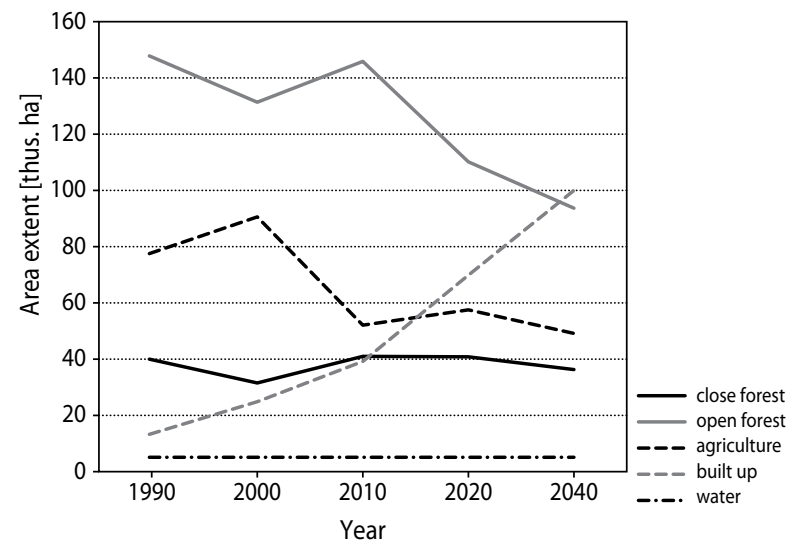

Figure 7. LULC Trends covering 1990-2040 


\section{Discussion}

\section{Remote Sensing and GIS in LULC Appraisal}

The optimal utilization of land and its resources requires an in-depth information of the historical, current and possible future scenarios. RS and GIS provide the tools expedient for monitoring the dynamics of LULC ensuing out of both the changing demands of increasing populace and elements of nature acting to influence the landscape (Appiah 2017; Joshi 2017). Natural and man-made processes continue the transformation of Earth's atmosphere and land (Khairullina et al. 2019; Gregory 2019). The appraisal of the spatio-temporal patterns of LULC in forests, rural, urban and other land use forms are necessary to the understanding of the evolution of forest loss, urban systems and other critical ecosystem services. Consequently, information about LULC extent, change and forecasting are essential for apprising land cover maps and the management of natural resources (Nampak et al. 2018; Cerbaro et al. 2020).

Satellite imagery deliver a proficient means of obtaining information (data) on spatial distribution and temporal trends of LULC required for quantifying, appraising, forecasting and projecting land changes (Tonneau and Maurel 2016; Domeneghetti et al. 2018). Additionally, in inaccessible terrain (such as mountainous, marshy, glacial and many others), remote sensing technique is feasibly the only method of procuring relevant data at a cost and time effective basis (Stead et al. 2019; Hakeem et al. 2018).

The old classical conservative ground methods of LULC are labour intensive, time consuming and are mostly done irregularly. The resultant maps from these processes rapidly become outmoded with the passage of time due the dynamic changes occurring in the world. Remote Sensing techniques on the other hand provides accurate LULC maps and monitoring changes at relatively less labour intensive, regular intervals of time and can be continuously updated (Mani and Varghese 2018; Alganci 2019). Despite the spatial and spectral heterogeneity challenges of agricultural lands (tree cash crops like cocoa, palm, oranges to perennial crops such as maize, rice, plantain) in Africa and urban environments, remote sensing remains the preferred choice as the suitable source of reliable information about the multiple facets of LULC (Pandey et al. 2019; Orynbaikyzy et al.
2019). To monitor and appraise dynamic changes (extent, patterns and trends) of LULC at local, continental and global levels, and for the exploration of the scope of future modifications, the geospatial techniques were used to produce good results.

\section{LULC trajectory}

LULC change detection appraisals have several inferences contingent on the scope and concentration of the researcher. However, the popular understanding of Change Detection application is its ability to provide information on changes in LULC covering extent, location and trend, and the spatial distribution of the change (Singh 1989; Zhu 2017).

The LULCC maps for 1990-2000, 2000-2010 and 2010-2020 gives a great cause for concern in the light of climate change concerns. LULC changes of $141,504.72$ ha $(49.69 \%), 130,354.25$ ha $(45.77 \%)$, $138,598.03$ ha $(48.67 \%)$ for the respective epoch years had transpired transitioning mostly into other land use classes. Deforestation is prevalent outside of the protected areas, while forest degradation is manifested in the protected areas as a result of logging (mostly illegal), illegal mining popularly called Galamsey and admitted agricultural activities. Cumulatively, urbanization is on the rise as the population continues to rise. LULCC in this study is clearly caused by anthropogenic forces. These findings concur with the earlier research undertaken (Koranteng and Zawila-Niedzwiecki 2015; Kleemann et al. 2017; Abass et al. 2019).

\section{Predicting the future land use changes}

Forecasting LULC has become critical in land and resource management (Trammell et al. 2018; Anand et al. 2018). The consolidative and combinative model of cellular automata and Markov chain were employed to forecast the future LULC pattern of the study area for the year 2040.

The forecast for the period 2040 indicate the human built-up class becoming the dominant LU in the study area. Mostly, the measurements display a growing trend in human-built environment, which is attributed to the increasing human population (GSS 2013). The Ashanti Region as the centre of the country with its rich natural resources and strategic location attracts migrants from different communities in Ghana and other nationals from West Africa and the continents. 


\section{Conclusion}

This study has demonstrated the significance of LULC in mid zone of Ghana in providing appropriate evidence in time for decision making concerning the forest loss, reduction in cropland and surging built-up areas. The techniques for extraction of LULC maps (1990, 2000, 2010, and 2020), and the model employed to forecast the future LULC (2040) through the CA-Markov modelling, have made possible to acquire information from examination of LULCs pertaining to the extent and type of each LULC, while demonstrating LULC conversions in the study area. Largely, the findings of this study specify that remote sensing images' classification (Supervised) is a vigorous means of extracting suitable LULC maps. The capacity of CA-Markov model in forecasting was ascertained to be satisfactory.

LULC investigation offer vital information for comprehensive global, continental, regional, countrywide and local environment change and sustainable development researches. These studies are useful for planning and management for decision-makers. In this study, a synergy of different satellite images (Landsat TM, Landsat ETM+, Disaster Monitoring Constellation-DMC, Alos and SENTINEL) using a long-time-series of (1990, 2000, 2010 and 2020) remote sensing images with varying resolution were employed to achieve comprehensive information of LULC. The study highlighted the forest loss (deforestation and degradation), surging built-up areas, reducing agricultural land and conversion processes in Ghana's Ashanti regional capital (Kumasi) and surrounding districts during the periods of 1990-2000, 2000-2010 and 2010-2020. The general pattern of LULC in the study area included forest loss, an expansion of built-up land, as well as a reduction in cropland. Water bodies remained fairly stable because the main water bodies (Lake Bosumtwi, Barekese Headworks and Owabi Headworks) in the study area are important national assets and are duly under protection.

The transition from forest and agriculture to built-up land have been the prevailing LULC patterns over the past 30 years. Forest (Close and Open) remains the dominant land-use type in the study area because the area hosts the Bobori Forest Reserve and the forests surrounding the Barekese and Owabi Headworks are protected areas. However, forest outside these protected areas have been greatly depleted and converted into other uses.
This study found the major developments of historical LULC transformations in the study area and projected these into the future for possible LULC transition processes. CA-Markov model is a convenient means for LULC prediction, the study affirmed. Consequently, the CA-Markov model is vital for LULC policy formulation and development.

\section{References}

Abass, K., Afriyie, K., Gyasi, R.M. 2019. From green to grey: the dynamics of land use/land cover change in urban Ghana. Landscape Research, 44 (8), 909-921.

Acheampong, M.,Yu.Q., Enomah, L.D., Anchang, J., Eduful, M. 2018. Land use/cover change in Ghana's oil city: Assessing the impact of neoliberal economic policies and implications for sustainable development goal number one-A remote sensing and GIS approach. Land Use Policy, 73, 373-384.

Aitkenhead, M.J., Aalders, I.H. 2009. Predicting land cover using GIS, Bayesian and evolutionary algorithm methods. Journal of Environmental Management, 90 (1), 236-250.

Alganci, U. 2019. Dynamic Land Cover Mapping of Urbanized Cities with Landsat 8 Multi-temporal Images: Comparative Evaluation of Classification Algorithms and Dimension Reduction Methods. ISPRS International Journal of Geo-Information, 8 (3), 139.

Anand, J., Gosain, A.K., Khosa, R. 2018. Prediction of land use changes based on Land Change Modeler and attribution of changes in the water balance of Ganga basin to land use change using the SWAT model. Science of the Total Environment, 644, 503-519.

Appiah, D.O. 2017. Geoinformation Modelling of PeriUrban Land Use and Land Cover Dynamics for Climate Variability and Climate Change in the Bosomtwe District, Ghana. Doctoral dissertation.

Arsanjani, J.J., Helbich, M., Kainz, W., Boloorani, A.D. 2013. Integration of logistic regression, Markov chain and cellular automata models to simulate urban expansion. International Journal of Applied Earth Observation and Geoinformation, 21, 265-275. 
Ayele, G.T. et al. 2018. Time Series Land Cover Mapping and Change Detection Analysis Using Geographic Information System and Remote Sensing, Northern Ethiopia. Air, Soil and Water Research, 11. DOI: https://doi.org/10.1177/1178622117751603

Behera, M.D., Borate, S.N., Panda, S.N., Behera, P.R., Roy, P.S. 2012. Modelling and analyzing the watershed dynamics using Cellular Automata (CA)Markov model-A geo-information based approach. Journal of Earth System Science, 121 (4), 1011-1024.

Bekele, D., Alamirew, T., Kebede, A., Zeleke, G., Melesse, A.M. 2019. Land use and land cover dynamics in the Keleta watershed, Awash River basin, Ethiopia. Environmental Hazards, 18 (3), 246-265.

Cerbaro, M., Morse, S., Murphy, R., Lynch, J., Griffiths, G. 2020. Information from Earth Observation for the Management of Sustainable Land Use and Land Cover in Brazil: An Analysis of User Needs. Sustainability, 12 (2), 489.

Domeneghetti, A., Tarpanelli, A., Grimaldi, L., Brath, A., Schumann, G. 2018. Flow duration curve from satellite: potential of a lifetime SWOT mission. Remote Sensing, 10 (7), 1107.

Eastman, J.R. 2012. IDRISI Selva Manual. Clark University, Worcester, MA, USA.

Etemadi, H., Smoak, J.M., Karami, J. 2018. Land use change assessment in coastal mangrove forests of Iran utilizing satellite imagery and CA-Markov algorithms to monitor and predict future change. Environmental Earth Sciences, 77 (5), 208.

Foody G.M. 2002. Status of land cover classification accuracy assessment. Remote Sensing of Environment, 80, 185-201.

FPP-PASCO-FC Report. 2013. Mapping of Forest Cover and Carbon Stock in Ghana - Pilot study which covered the SECOND and THIRD TIERS recommended in the Good Practice Guidelines of the Intergovernmental Panel on Climate Change (IPCCGPG) for REDD+ planning.

Glinskis, E.A., Gutiérrez-Vélez, V.H. 2019. Quantifying and understanding land cover changes by large and small oil palm expansion regimes in the Peruvian Amazon. Land Use Policy, 80, 95-106.

Goswami, M., Ravishankar, C., Nautiyal, S., Schaldach, R. 2019. Integrated Landscape Modelling in India: Evaluating the Scope for Micro-Level Spatial
Analysis over Temporal Scale. In: Tropical Ecosystems: Structure, Functions and Challenges in the Face of Global Change, 289-315. Springer, Singapore.

Gregory, K.J. 2019. Man and environmental processes: a physical geography perspective. Routledge.

GSS. 2013. 2010 Population and Housing Census National analytical report. Accra, Ghana.

Guan, D., Zhao, Z., Tan, J. 2019. Dynamic simulation of land use change based on logistic-CA-Markov and WLC-CA-Markov models: a case study in three gorges reservoir area of Chongqing, China. Environmental Science and Pollution Research, 26 (20), 20669-20688.

Hakeem, K.A., Abirami, S., Rao, V.V., Diwakar, P.G., Dadhwal, V.K. 2018. Updated inventory of Glacial Lakes in Teesta Basin using remote sensing data for use in GLOF risk assessment. Journal of the Indian Society of Remote Sensing, 46 (3), 463-470.

He, J., Li, X., Yao, Y., Hong, Y., Jinbao, Z. 2018. Mining transition rules of cellular automata for simulating urban expansion by using the deep learning techniques. International Journal of Geographical Information Science, 32 (10), 2076-2097.

Hyandye, C., Martz, L.W. 2017. A Markovian and cellular automata land-use change predictive model of the Usangu Catchment. International Journal of Remote Sensing, 38 (1), 64-81.

Issa, A.F.E. 2018. Assessment of the Vegetation Cover Change at Qala El-Nahal Locality-Gedaref StateSudan. Doctoral dissertation. Sudan University of Science and Technology.

Joshi, J.P. 2017. Modelling Urban Sprawl Dynamics For Vadodara Urban Region Integrating Cellular Automata and GIS. Doctoral dissertation. The Maharaja Sayajirao University of Baroda.

Khairullina, E.R., Bogdanova, V.I., Slepneva, E.V., Nizamutdinova, G.F., Fatkhullina, L.R., Kovalenko, Y.A., Skutelnik, O.A. 2019. Global climate change: cyclical nature of natural and permanent nature of man-made processes. EurAsian Journal of BioSciences, 13, 2311-2316.

Kleemann, J., Baysal, G., Bulley, H.N., Fürst, C. 2017. Assessing driving forces of land use and land cover change by a mixed-method approach in north-eastern Ghana, West Africa. Journal of Environmental Management, 196, 411-442. 
Koranteng, A., Zawiła-Niedźwiecki, T. 2015. Modelling forest loss and other land use change dynamics in Ashanti Region of Ghana. Folia Forestalia Polonica, Ser. A-Forestry, 57 (2), 96-111.

Liping, C., Yujun, S., Saeed, S. 2018. Monitoring and predicting land use and land cover changes using remote sensing and GIS techniques-A case study of a hilly area, Jiangle, China. PloS ONE, 13 (7), e0200493.

Lu D., Mausel, P., Brondízio, E., Moran, E. 2004. Change detection techniques. International Journal of Remote Sensing, 25 (12), 2365-2401.

Mani, J.K., Varghese, A.O. 2018. Remote Sensing and GIS in Agriculture and Forest Resource Monitoring. In: Geospatial Technologies in Land Resources Mapping, Monitoring and Management, 377-400. Springer, Cham.

Mansour, S., Al-Belushi, M., Al-Awadhi, T. 2020. Monitoring land use and land cover changes in the mountainous cities of Oman using GIS and CAMarkov modelling techniques. Land Use Policy, 91. DOI: 10.1016/j.landusepol.2019.104414

Melese, S.M. 2016. Effect of land use land cover changes on the forest resources of Ethiopia. International Journal of Natural Resource Ecology and Management, 1 (2), 51.

Memarian, H., Balasundram, S.K., Talib, J.B., Sung, C.T.B., Sood, A.M., Abbaspour, K. 2012. Validation of CA-Markov for Simulation of Land Use and Cover Change in the Langat Basin, Malaysia. Journal of Geographic Information System, 4 (6), 542-554.

Menon, S., Bawa, K.S. 1997. Applications of geographic information systems, remote-sensing, and a landscape ecology approach to biodiversity conservation in the Western Ghats. Current Science, 73 (2), 134-145.

Michetti, M., Zampieri, M. 2014. Climate-humanland interactions: A review of major modelling approaches. Land, 3 (3), 793-833. DOI:10.3390/ land3030793

Monserud, R.A., Leamans, R. 1992. Comparing global vegetation maps with the kappa statistic. Ecological Modelling, 62, 275-293.

Mosammam, H.M., Nia, J.T., Khani, H., Teymouri, A., Kazemi, M. 2017. Monitoring land use change and measuring urban sprawl based on its spatial forms:
The case of Qom city. The Egyptian Journal of Remote Sensing and Space Science, 20 (1), 103-116.

Muller, M.R., Middleton, J. 1994. A Markov model of land-use change dynamics in the Niagara Region, Ontario, Canada. Landscape Ecology, 9 (2), 151-157.

Nampak, H., Pradhan, B., Mojaddadi Rizeei, H., Park, H.J. 2018. Assessment of land cover and land use change impact on soil loss in a tropical catchment by using multitemporal SPOT $\square 5$ satellite images and $\mathrm{R}$ evised $\mathrm{U}$ niversal Soil $\mathrm{L}$ oss E quation model. Land Degradation and Development, 29 (10), 3440-3455.

Navarro-Cerrillo, R.M., Esteves Vieira, D.J., OchoaGaona, S. 2019. Journal of Forestry Research, 30, 143. DOI: https://doi.org/10.1007/s11676-0170568-3

Orynbaikyzy, A., Gessner, U., Conrad, C. 2019. Crop type classification using a combination of optical and radar remote sensing data: a review. International Journal of Remote Sensing, 40 (17), 6553-6595.

Pandey, P.C., Koutsias, N., Petropoulos, G.P., Srivastava, P.K., Ben Dor, E. 2019. Land use/land cover in view of earth observation: data sources, input dimensions, and classifiers - a review of the state of the art. Geocarto International, 1-32.

Parsa, V.A., Yavari, A., Nejadi, A. 2016. Spatio-temporal analysis of land use/land cover pattern changes in Arasbaran Biosphere Reserve: Iran. Modeling Earth Systems and Environment, 2 (4), 1-13.

Panwar, S., Malik, D.S. 2017. Evaluating Land Use/ Land Cover Change Dynamics in Bhimtal Lake Catchment Area, Using Remote Sensing and GIS Techniques. Journal of Remote Sensing and GIS, 6 (199), 2.

Pervez, W., Uddin, V., Khan, S.A., Khan, J.A. 2016. Satellite-based land use mapping: comparative analysis of Landsat-8, Advanced Land Imager, and big data Hyperion imagery. Journal of Applied Remote Sensing, 10.

Pontius, R.G. 2000. Quantification error versus location error in comparison of categorical Maps. Photogrammetric Engineering and Remote Sensing, 66, 1011-1016.

Qader, S.H., Dash, J., Atkinson, P.M., Rodriguez-Galiano, V. 2016. Classification of vegetation type in 
Iraq using satellite-based phenological parameters. IEEE Journal of Selected Topics in Applied Earth Observations and Remote Sensing, 9 (1), 414-424.

Rai, R., Zhang, Y., Paudel, B., Li, S., Khanal, N.R. 2017. A synthesis of studies on land use and land cover dynamics during 1930-2015 in Bangladesh. Sustainability, 9 (10), 1866.

Ralha, C.G., Abreu, C.G., Coelho, C.G.C., Zaghetto, A., Macchiavello, B., Machado, R.B. 2013. A multiagent model system for land-use change simulation. Remote Sensing of Environment, 42, 30-46.

Rimal, B., Zhang, L., Keshtkar, H., Wang, N., Lin, Y. 2017. Monitoring and modeling of spatiotemporal urban expansion and land-use/land-cover change using integrated markov chain cellular automata model. ISPRS International Journal of Geo-Information, 6 (9), 288.

Ronchi, S. 2018. Ecosystem Services For Spatial Planning: Innovative Approaches and Challenges for Practical Applications. Springer.

Sang, L., Zhang, C., Yang, J., Zhu, D., Yun, W. 2011. Simulation of land use spatial pattern of towns and villages based on CA-Markov model. Mathematical and Computer Modelling, 54 (3), 938-943.

Shamsi, S.R.F. 2010. Integrating Linear Programming and Analytical Hierarchical Processing in RasterGIS to Optimize Land Use Pattern at Watershed Level. Journal of Applied Sciences and Environmental Management, 14 (2), 81-85.

Singh, A. 1989. Digital change detection techniques using remotely sensed data. International Journal of Remote Sensing, 10 (6), 989-1003.

Singh, S.K., Mustak, S., Srivastava, P.K., Szabó, S., Islam, T. 2015. Predicting Spatial and Decadal LULC Changes Through Cellular Automata Markov Chain Models Using Earth Observation Datasets and Geo-information. Environmental Processes, 2 (1), 61-78.

Singh, P., Kikon, N., Verma, P. 2017. Impact of land use change and urbanization on urban heat island in Lucknow city, Central India. A remote sensing based estimate. Sustainable Cities and Society, 32, 100-114.

Sohl, T.L., Claggett, P.R. 2013. Clarity versus complexity: Land-use modeling as a practical tool for decision-makers. Journal of Environmental Management, 129, 235-243.
Srivastava, P.K., Singh, S.K., Gupta, M., Thakur, J.K., Mukherjee, S. 2013. Modeling Impact of Land Use Change Trajectories on Groundwater Quality Using Remote Sensing and GIS. Environmental Engineering and Management Journal, 12, 2343-2355.

Stead, D., Donati, D., Wolter, A., Sturzenegger, M. 2019. Application of Remote Sensing to the Investigation of Rock Slopes: Experience Gained and Lessons Learned. ISPRS International Journal of Geo-Information, 8 (7), 296.

Stefanov, W.L., Ramsey, M.S., Christensen, P.R. 2001. Monitoring urban land cover change: An expert system approach to land cover classification of semiarid to arid urban centers. Remote Sensing of Environment, 77 (2), 173-185.

Stevens, D., Dragićević, S. 2007. A GIS-Based Irregular Cellular Automata Model of Land-Use Change. Environment and Planning B: Urban Analytics and City Science, 34 (4), 708-724.

Subedi, P., Subedi, K., Thapa, B. 2013. Application of a Hybrid Cellular Automaton-Markov (CA-Markov) Model in Land-Use Change Prediction: A Case Study of Saddle Creek Drainage Basin, Florida. Science and Education, 1 (6), 126-132.

Tonneau, J.P., Maurel, P. 2016. Satellite imagery: a tool for territorial development. In: Land surface remote sensing in urban and coastal areas, 101-139. Elsevier.

Trammell, E.J., Thomas, J.S., Mouat, D., Korbulic, Q., Bassett, S. 2018. Developing alternative land-use scenarios to facilitate natural resource management across jurisdictional boundaries. Journal of Environmental Planning and Management, 61 (1), 64-85.

Zhang, C., Chen, Y., Lu, D. 2015. Detecting fractional land-cover change in arid and semiarid urban landscapes with multitemporal Landsat Thematic mapper imagery. GIScience and Remote Sensing, 52 (6), 700-722.

Zhao, L., Peng, Z.-R. 2012. LandSystem: an agentbased Cellular Automata model of land use change developed for transportation analysis. Journal of Transport Geography, 25, 35-49.

Zhu, Z. 2017. Change detection using landsat time series: A review of frequencies, preprocessing, algorithms, and applications. ISPRS Journal of Photogrammetry and Remote Sensing, 130, 370-384. 